\title{
Relationship Between Host Acidification and Virulence of Penicillium spp. on Apple and Citrus Fruit
}

\author{
Dov Prusky, James L. McEvoy, Robert Saftner, William S. Conway, and Richard Jones
}

First, second, third, and fourth authors: Produce Quality and Safety Laboratory; fifth author: Vegetable Laboratory, Henry A. Wallace Beltsville Agricultural Research Center, U.S. Department of Agriculture-Agricultural Research Service, Beltsville, MD 20705; and first author: Department of Postharvest Science of Fresh Produce, Institute for Technology and Storage of Agricultural Products, the Volcani Center, Agricultural Research Organization, Bet Dagan 50250, Israel. Accepted for publication 7 July 2003.

\begin{abstract}
Prusky, D., McEvoy, J. L., Saftner, R., Conway, W. S., and Jones, R. 2004. Relationship between host acidification and virulence of Penicillium spp. on apple and citrus fruit. Phytopathology 94:44-51.

Penicillium expansum, $P$. digitatum, and $P$. italicum acidify the ambient environments of apple and citrus fruit during decay development. They use two mechanisms for this: the production of organic acids, mainly citric and gluconic, and $\mathrm{NH}_{4}{ }^{+}$utilization associated with $\mathrm{H}^{+}$ efflux. Exposure of $P$. expansum and $P$. digitatum hyphae to $\mathrm{pH} 5.0$ increased their citric acid production, compared with the production of organic acids at acidic ambient $\mathrm{pH}$. In decayed fruit, both pathogens produced significant amounts of citric and gluconic acids in the decayed tissue and reduced the host $\mathrm{pH}$ by 0.5 to 1.0 units. Ammonium depletion

ambient $\mathrm{pH}$ reduction. Analysis of transcripts encoding the endopolygalacturonase gene, pepg 1 , from $P$. expansum accumulated under acidic culture conditions from $\mathrm{pH} 3.5$ to 5.0, suggesting that the acidification process is a pathogenicity enhancing factor of Penicillium spp. This hypothesis was supported by the finding that cultivars with lower $\mathrm{pH}$ and citric acid treatments to reduce tissue $\mathrm{pH}$ increased $P$. expansum development, presumably by increasing local $\mathrm{pH}$. However, organic acid treatment could not enhance decay development in naturally acidic apples. Conversely, local alkalinization with $\mathrm{NaHCO}_{3}$ reduced decay development. The present results further suggest that ambient $\mathrm{pH}$ is a regulatory cue for processes linked to pathogenicity of postharvest pathogens, and that specific genes are expressed as a result of the modified host $\mathrm{pH}$ created by the pathogens.
\end{abstract} from the growth medium or from the fruit tissue was directly related to
Penicillium expansum, $P$. digitatum, and $P$. italicum are filamentous ascomycete phytopathogens that attack a wide range of deciduous and tropical fruits. The pathogens macerate the host tissue and produce significant amounts of hydrolytic enzymes, with polygalacturonase (PG) being especially abundant (44). PGs have been implicated as colonization and virulence factors in several plant-infecting fungi, particularly in diseases characterized by tissue maceration or soft rot. Abundant correlative evidence supports the role of PGs in pathogenesis $(2,3,13,14,20,21,27)$. The disruption of $\mathrm{PG}$ genes reduces virulence, which suggests that this enzyme is a significant virulence factor in several plant-infecting fungi $(33,34)$. However, in several other cases, disruption of cell wall-degrading enzymes caused only partial or no reduction in pathogenicity, suggesting that not all enzymes produced by the pathogen are required for pathogenicity (33).

Prusky et al. (29) have suggested that pathogens may enhance their virulence by locally modulating the host's ambient $\mathrm{pH}$. This mechanism ensures that genes encoding cell wall-degrading extracellular enzymes are expressed and that their products secreted under the optimal $\mathrm{pH}$ conditions for their functioning $(9,11,29)$. This is consistent with the finding that, although several genes encode cell wall-degrading enzymes, only specific ones are activated during pathogenicity in vivo (29).

In the case of Sclerotinia sclerotiorum, the secretion of oxalic acid during infection creates the acidic environment necessary for activity of the PG produced by this fungus (19). In Colletotrichum

Corresponding author: D. Prusky; E-mail address: dovprusk@agri.gov.il

Publication no. P-2003-1105-01R

This article is in the public domain and not copyrightable. It may be freely reprinted with customary crediting of the source. The American Phytopathological Society, 2004. spp.-avocado fruit interactions, the alkalinization of host tissue during fruit ripening (42), and the localized alkalinization induced by the pathogen's secretion of ammonia, result in an appropriate $\mathrm{pH}$ for expression of pelB and the secretion of pectate lyase (29). Similar results were obtained for Alternaria alternata; it, too, induced secretion of ammonia and elicited the $\mathrm{pH}$ increase needed for the expression of $A a K 1$, an endo-1,4- $\beta$-glucanase (11). Preliminary experiments in our laboratory also indicated that Penicillium spp. colonization is enhanced by low $\mathrm{pH}$ in the host tissue (28). Together, these results suggest that environmental $\mathrm{pH}$ is important as a global regulator for enhancing the virulence of several postharvest pathogens.

Our objectives in the present study were to (i) determine if virulence is enhanced under acidic conditions in the host, and evaluate the importance of the pathogen in the regulation of ambient $\mathrm{pH}$ during pathogenicity by Penicillium spp.; (ii) identify the mechanism or mechanisms of ambient $\mathrm{pH}$ modulation by fungi; and (iii) determine if ambient $\mathrm{pH}$ affects the transcriptional regulation of pepg 1 in $P$. expansum. We hypothesized that ambient host $\mathrm{pH}$ and Penicillium spp.-induced host acidification control the pepg1 expression necessary for host tissue maceration by this pathogen.

\section{MATERIALS AND METHODS}

$\boldsymbol{P}$ expansum growth conditions. We utilized a wild-type $P$. expansum isolate obtained from a decayed 'Golden Delicious' apple at Beltsville Agricultural Research Center, U.S. Department of Agriculture-Agricultural Research Service (USDA-ARS), Beltsville, MD. This was the isolate from which PG was purified (41) and it is routinely cultured on potato dextrose agar (PDA; Difco Laboratories, Detroit). The $P$. italicum and $P$. digitatum isolates were obtained from J. L. Smilanick, USDA-ARS, Parlier, 
CA. Apple and citrus cultivars were obtained from local suppliers on the day of the experiment. To analyze the effects of ambient $\mathrm{pH}$ and carbon source on organic acid production, we inoculated $50 \mathrm{ml}$ of $\mathrm{M}_{3} \mathrm{~S}$ medium containing, per liter, $1 \mathrm{~g}$ of yeast extract (Difco Laboratories), $1 \mathrm{~g}$ of Bacto peptone (Difco Laboratories), $10 \mathrm{~g}$ of sucrose, $2.7 \mathrm{~g}$ of $\mathrm{KH}_{2} \mathrm{PO}_{4}$, and $2.5 \mathrm{~g}$ of $\mathrm{MgSO}_{4} \cdot 7 \mathrm{H}_{2} \mathrm{O}$ at $\mathrm{pH} 5.5$, in a $125-\mathrm{ml}$ flask with $1 \times 10^{7}$ spores $/ \mathrm{ml}$ obtained from a 7- to 10-day-old sporulating culture. This liquid culture was incubated for 2 days at $25^{\circ} \mathrm{C}$ with shaking at $150 \mathrm{rpm}$, and then was blended with an emulsifying blender (Bonjour, Pacheco, CA) and incubated for an additional $24 \mathrm{~h}$. The entire culture was harvested by vacuum filtration onto sterile filter paper (Whatman no. 1) and washed twice under vacuum with $50 \mathrm{ml}$ of sterile distilled water. The washed mycelia (average wet weight, $1.2 \mathrm{~g}$ ) were resuspended in $50 \mathrm{ml}$ of fresh inducing medium containing, per liter, $4 \mathrm{~g}$ of yeast extract, $1 \mathrm{~g}$ of $\mathrm{K}_{2} \mathrm{HPO}_{4}, 0.5 \mathrm{~g}$ of $\mathrm{MgSO}_{4} \cdot 7 \mathrm{H}_{2} \mathrm{O}$, and $15 \mathrm{~g}$ of sucrose (yeast sucrose medium [YSM]). Four flasks were inoculated for each initial $\mathrm{pH}$ value of 3.0, 5.0, or 7.0 that was adjusted with $0.5 \mathrm{M} \mathrm{HCl}$ and $0.5 \mathrm{~N} \mathrm{NaOH}$. These cultures were incubated for an additional $24 \mathrm{~h}$. These secondary cultures in inducing medium were harvested by vacuum filtration; the supernatants were saved for $\mathrm{pH}$ determination and organic acid quantification and the hyphae for dry weight determination.

In experiments in which the effect of $P$. expansum on $\mathrm{NH}_{4}^{+}$ influx (depletion from the medium) was determined, the washed mycelia resulting from growth on $\mathrm{M}_{3} \mathrm{~S}$ were resuspended in $50 \mathrm{ml}$ of fresh inducing medium containing, per liter, $0.5 \mathrm{~g}$ of $\mathrm{NH}_{4} \mathrm{Cl}$, $4 \mathrm{~g}$ of $\mathrm{K}_{2} \mathrm{HPO}_{4}, 2 \mathrm{~g}$ of $\mathrm{MgSO}_{4} \cdot 7 \mathrm{H}_{2} \mathrm{O}, 0.3 \mathrm{~g}$ of $\mathrm{CaCl}_{2} \cdot 2 \mathrm{H}_{2} \mathrm{O}$, $0.03 \mathrm{~g}$ of $\mathrm{FeCl}_{3}$, and $5 \mathrm{~g}$ of glucose, and the $\mathrm{pH}$ was adjusted to 5.0 with $1 \mathrm{~N} \mathrm{NaOH}$. These secondary cultures were harvested by vacuum filtration, the supernatants were saved for $\mathrm{pH}$ determination and $\mathrm{NH}_{4}{ }^{+}$quantification, and the hyphae were saved for dry weight determination.

Inoculation of fruit was carried out by wounding the fruit on four sides to a depth of 2 to $3 \mathrm{~mm}$ and placing $25 \mu \mathrm{l}$ of spore suspension $\left(0.5 \times 10^{6}\right.$ spores $\left./ \mathrm{ml}\right)$ into each wound. The fruit then were incubated for 4 days at $20^{\circ} \mathrm{C}$ and $90 \%$ relative humidity. In some experiments, fruit wound sites were treated with $25 \mu \mathrm{l}$ of citric (3 g/liter) or gluconic (15 g/liter) acid or $\mathrm{NaHCO}_{3}(140 \mathrm{mM})$ $1 \mathrm{~h}$ before pathogen inoculation. In vivo and in vitro experiments were repeated at least three times. The results of one representative experiment are presented. Standard errors (SEs) of the means were calculated.

Partial purification of PG produced by $\boldsymbol{P}$. expansum. Apple fruit were washed in soapy water and surface disinfested with $80 \%$ ethanol. They then were wound inoculated with a spore suspension of $P$. expansum $\left(0.5 \times 10^{6}\right.$ spores $\left./ \mathrm{ml}\right)$. After 13 days of incubation at $20^{\circ} \mathrm{C}$, the peel over the lesion was removed and the decayed cortical tissue was collected for PG extraction. The extraction procedure, which was a modification of one previously used (44), was carried out at $5^{\circ} \mathrm{C}$. The decayed cortical tissue $(500 \mathrm{~g})$ was homogenized in an equal volume of a solution containing $20 \mathrm{mM}$ 2-[N-morpholino]-ethanesulfonic acid (MES), $1 \mathrm{M} \mathrm{NaCl}$, and $1.5 \%$ water-insoluble polyvinylpyrrolidone. The homogenate was adjusted to $\mathrm{pH} 6.0$, stirred for $30 \mathrm{~min}$, and filtered through cheesecloth followed by Miracloth (CalbiochemBoehring, La Jolla, CA). The filtrate was centrifuged at 20,000 $\times g$ for $30 \mathrm{~min}$. The supernatant was concentrated to $100 \mathrm{ml}$ by a Minitan ultrafiltration system equipped with $10-\mathrm{kDa}$ cut-off low protein-binding membranes (Millipore Corp., Bedford, MA). The filtrate was centrifuged at $20,000 \times g$ for $30 \mathrm{~min}$ and the supernatant was concentrated further to $15 \mathrm{ml}$ in a stirred-cell ultrafiltration system fitted with a $10-\mathrm{kDa}$ cut-off membrane (Amicon, Beverly, MA). The concentrate was dialyzed against deionized water overnight.

The activity of PG in the concentrate was determined by measuring reducing groups released from sodium polypectate, with D-galacturonic acid as the standard, according to Yao et al.
(44). One unit of PG activity was defined as the amount of enzyme required to release $1 \mu \mathrm{mol}$ of reducing groups per minute under the assay conditions employed. The PG extract was filter sterilized and used to treat apple tissue. The sterilized crude PG extract exhibited a total activity of 320 units and a specific activity of 230 units/mg.

Organic acid quantification. Organic acid levels were measured in supernatants from cultures of $P$. expansum and $P$. digitatum, healthy and $P$. expansum-decayed apples, and healthy and $P$. digitatum-decayed grapefruit. For organic acid measurements, supernatants from cultures grown on different carbon sources and at various $\mathrm{pH}$ levels and filtered extracts of healthy and decayed tissues were analyzed. Samples (20 $\mu \mathrm{l}$ each) were injected onto a PLRP-S column (250 by $4.6 \mathrm{~mm}$; Polymer Laboratories, Amherst, MA). The mobile phase was $0.5 \%$ perchloric acid and the flow rate was maintained at $1.0 \mathrm{ml} / \mathrm{min}$. Oxalic acid was detected with a Model 400 electrochemical detector (EG\&G, Princeton, NJ) with a glassy carbon electrode set at $1,150 \mathrm{mV}$. The peak height was quantified and compared with an external standard curve, with oxalic acid dihydrate (Sigma-Aldrich, St Louis) as the standard. For acids other than oxalic, $5 \mathrm{ml}$ of $0.1 \mathrm{~N} \mathrm{H}_{2} \mathrm{SO}_{4}$ was added to 1-g tissue samples, the mixture was homogenized for $30 \mathrm{~s}$ with a Polytron (Brinkmann Instruments, Westbury, NY), and the extract was passed through a $0.45-\mu$ m nylon filter. The final extract volume was $5.9 \mathrm{ml}$. Aliquots $(20 \mu \mathrm{l}$ each) of supernatants, tissue extracts, and organic acid standards were injected onto a Lonpak KC-810P precolumn (6 by $50 \mathrm{~mm}$; Shodex, Tokyo) and a Lonpak KC-811 column ( 8 by $300 \mathrm{~mm}$ ) maintained at $50^{\circ} \mathrm{C}$. The mobile phase was $0.002 \mathrm{~N} \mathrm{H}_{2} \mathrm{SO}_{4}$, and the flow rate was maintained at $1.5 \mathrm{ml} / \mathrm{min}$ with a Model 110B pump (Brinkmann Instruments, Columbia, MD). A Model 400 electrochemical detector (EG\&G) with a glassy carbon electrode set at $750 \mathrm{mV}$ was used for ascorbic acid quantitation and a Model LC-95 UV detector (Perkin-Elmer, Norwalk, CT) set at $200 \mathrm{~nm}$ was used for other organic acids. The peak height for each acid detected in the samples was quantified and compared with an external standard curve based on the appropriate acid standard obtained from SigmaAldrich. All data for organic acid analyses were collected with a Millennium 32 Chromatography Manager (Waters, Milford, CT).

pH measurements. $\mathrm{pH}$ was measured directly with a microcombination $\mathrm{pH}$ electrode Model 9810BN (Orion, Beverly, MA) in 1- to 3-ml aliquots sampled at different times after fungal inoculation, and four replicates were tested for each treatment. Mesocarp $\mathrm{pH}$ was determined along a transverse cut through the infection site, made with a scalpel blade. $\mathrm{pH}$ measurements were taken by placing the micro $\mathrm{pH}$ electrode directly against the exposed tissue, as described previously (29). All measurements were repeated on 10 to 12 fruit (at least 30 measurements) on the transverse axis of the lesion of each fruit. The SEs of the means of $\mathrm{pH}$ measurements were never higher than $2.5 \%$.

Detection of ammonium in the liquid medium and in the tissue. Ammonium concentration was determined in filtered culture medium or tissue extract. Tissue extract was obtained by crushing 2 to $4 \mathrm{~g}$ of cortical tissue with a glass rod and centrifuging the liquid through a 4-mm-diameter 0.45 - $\mu \mathrm{m}$ filter (Eppendorf Scientific, Inc., Westbury, NY) at 4,000 $\times g$. Ammonium was measured at different times after inoculation with an ammonia electrode Model 95-12 (Orion) in 0.1- to 1-ml aliquots (depending upon the concentration) after the $\mathrm{pH}$ of the samples had been adjusted to 10.0 with $10 \mathrm{~N} \mathrm{NaOH}$. Different concentrations of $\mathrm{NH}_{4} \mathrm{Cl}$ in the range of 7 to $700 \mu \mathrm{M}$ were used as standards. Experiments with three replications were repeated at least three times. The results of one representative experiment are presented. SEs of the means were calculated. The ATPase inhibitors, Na orthovanadate at 100 to $200 \mu \mathrm{M}$, and diethylstilbestrol at $20 \mu \mathrm{M}$ (Sigma-Aldrich) were added to the ammonium medium and residual ammonium concentrations were determined $20 \mathrm{~h}$ later as previously described (26). 
Polymerase chain reaction subcloning to generate hybridization probes for pepg1 from $P$. expansum. Two DNA fragments corresponding to nucleotides 1007 to 1386 and 1705 to 2018 from the $P$. expansum pepg 1 gene (accession no. AF047713) were amplified by polymerase chain reaction (PCR) of genomic DNA with the following primers: PE1006 (TGAGGGAACCACTACTTTCG) plus PE1385 (CGTTCCAGAATTGATAGCAAG) and PE1704 (TGTCAAGGCTGTCTCTGG) plus PE2017 (AAGTGCCGGAAGGTGC), respectively. The fragments were cloned into pCRII with a TOPO TA Cloning Kit (Invitrogen, Carlsbad, CA) to generate pCRPG2 and pCRPG, respectively. The 423-bp fragment in pCRPG2 corresponded to exon 2 and the 313-bp fragment in pCRPG1 corresponded to exon 4 of the $3^{\prime}$ untranslated region (UTR) of pepg 1 . Both probes were used separately to repeat and confirm the Northern analyses. Genomic DNA was isolated from the mycelium of $P$. expansum with a DNeasy QIAGEN kit (Qiagen, Santa Clarita, CA).

Sequence analysis of the PCR-generated fragments of pepg1. Plasmid pCRPG containing the genomic sequences of pepg 1 were used as DNA sequencing templates. The sequence of both strands of each subcloned fragment were confirmed (DNA Sequencing Facility, University of Maryland, College Park). Homology to the pepg 1 was determined with the BLAST algorithm (accession no. AF047713) and was conducted with the Wisconsin Sequence Analysis Program 9.1 (Genetics Computer Group, Madison, WI).

Northern analysis. Primary cultures were grown and harvested as described above. For experiments to determine the effect of ambient $\mathrm{pH}$ on pepg 1 , harvested cultures were transferred to fresh YSM buffered with $0.5 \mathrm{M}$ citric acid-sodium phosphate buffer to achieve initial $\mathrm{pH}$ values between 3.0 and 7.0; the actual initial $\mathrm{pH}$ value for each culture was determined after autoclaving. These secondary cultures were incubated for 2,5 , or $7 \mathrm{~h}$, harvested by vacuum filtration, and quickly frozen in liquid nitrogen. Total RNAs were prepared with the FastRNA Kit-RED (BIO 101, Carlsbad, CA). Total RNAs (20 $\mu \mathrm{g} / \mathrm{lane})$ were separated in a $1.2 \%$ agarose, 0.36 $\mathrm{M}$ formaldehyde/MOPS gel, transferred to a Hybond- $\mathrm{N}^{+}$nylon membrane (Amersham, Arlington Heights, IL), fixed by incubating for $2 \mathrm{~h}$ at $80^{\circ} \mathrm{C}$, hybridized overnight in a hybridization incubator (Robbins Scientific, Sunnyvale, CA) with $1 \%$ bovine serum albumin, $0.25 \mathrm{M} \mathrm{Na}_{2} \mathrm{HPO}_{4}$, and $7 \%$ sodium dodecyl sulfate (SDS) solution at $65^{\circ} \mathrm{C}$, followed by three washes of $45 \mathrm{~min}$ each at $65^{\circ} \mathrm{C}(2 \times \mathrm{SSC}[1 \times \mathrm{SSC}$ is $0.15 \mathrm{M} \mathrm{NaCl}$ plus $0.015 \mathrm{M}$ sodium citrate] $+0.5 \% \mathrm{SDS} ; 1 \times \mathrm{SSC}+0.5 \% \mathrm{SDS}$; and $0.1 \times$ SSC $+0.5 \%$ SDS) as described by Church and Gilbert (7), and autoradiographed essentially as described by Ausubel et al. (1). An RNA ladder standard (GibcoBRL) was used to estimate the lengths of the RNAs. Probes were synthesized with a random priming kit with ${ }^{32} \mathrm{P}$-dATP as the label (Boehringer Mannheim, Indianapolis, IN). For all hybridizations, a ${ }^{32} \mathrm{P}(\mathrm{dATP})$-labeled probe was diluted to $1 \times 10^{6} \mathrm{dpm} / \mathrm{ml}$. The sequences used for hybridization were two probes of the endopolygalacturonase-en- coding pepg 1 coding sequence (41) (accession no. AF047713) and the rDNA repeat sequence from Neurospora crassa from pMF2 (12). The washed blot was autoradiographed and exposed to a Fuji BAS (Bio Analyzing System) sample screen. Images were captured with a Fuji BAS reader (Fujifilm, Tokyo). Hybridization signals were quantified with MacBAS software version 2.3 (Fujifilm). The reported relative level of signals in each lane was corrected based on the background intensity and hybridization signal from the rDNA probe.

\section{RESULTS}

The relationship between $\mathrm{pH}$ decrease and decay development by Penicillium spp. in apple and citrus fruit. $P$. expansum decayed 'Granny Smith', 'Gala', 'Red Delicious', 'Fuji', and 'Golden Delicious' apple fruit within 4 to 6 days after inoculation. The $\mathrm{pH}$ in nondecayed tissue ranged between 4.0 and 4.5 (Table $1)$; whereas, in the center of the decayed tissue $(\approx 15-\mathrm{mm}$ in diameter), the $\mathrm{pH}$ decreased to 3.6 to 4.1 . The $\mathrm{pH}$ values at the edge of the decayed tissue and the adjacent edge of the healthy tissue were very similar to those observed in the decayed and healthy tissue, respectively (data not shown). $P$. digitatum and $P$. italicum isolates caused decay symptoms 5 to 6 days after inoculation of citrus fruit and decreased the $\mathrm{pH}$ of the tissue from 4.6 to 4.8 in the healthy tissue to 3.0 to 3.2 in the decayed lesion (Table 1).

The relationship between apple flesh $\mathrm{pH}$ and colonization by $P$. expansum was examined by using cultivars with differing initial $\mathrm{pH}$ and by local modulation of the tissue $\mathrm{pH}$. The sizes of the decay lesions caused by $P$. expansum infection in the three apple cvs. Fuji, Rome, and Granny Smith increased as the $\mathrm{pH}$ of the untreated tissue decreased from 4.5 to 3.8 (Table 2). Similarly, treatment of Fuji fruit, which has an untreated tissue $\mathrm{pH}$ of 5.3, with citric or gluconic acid enhanced $P$. expansum decay development, but the same treatment did not affect decay development in Golden Delicious apples, which had a pH of 4.4 (Fig. 1). However, treatment of Golden Delicious apples with a $140-\mathrm{mM}$ $\mathrm{NaHCO}_{3}$ solution resulted in an increase of $\mathrm{pH}$ to 7.1 and to reduced $P$. expansum-induced decay (Fig. 2). Similar results were obtained in $\mathrm{NaHCO}_{3}$-treated Fuji fruit (data not shown).

TABLE 2. The relationship between apple $\mathrm{pH}$ and Penicillium expansum decay development ${ }^{\mathrm{z}}$

\begin{tabular}{lcc}
\hline Cultivar & $\mathrm{pH}$ at inoculation & Decay diameter $(\mathrm{mm})$ \\
\hline Fuji & $4.46 \pm 0.01$ & $12 \pm 0.2$ \\
Rome & $3.77 \pm 0.03$ & $17 \pm 0.1$ \\
Granny Smith & $3.45 \pm 0.02$ & $21 \pm 0.5$ \\
\hline
\end{tabular}

${ }^{\mathrm{z}}$ Average $\mathrm{pH}$ values \pm standard error. $\mathrm{pH}$ was measured directly with a microcombination $\mathrm{pH}$ electrode Model 9810BN (Orion, Beverly, MA). All measurements were repeated on 10 to 12 fruit (at least 30 measurements) on the transverse axis of the lesion of each fruit.

TABLE 1. pH levels in healthy and Penicillium-decayed fruit

\begin{tabular}{|c|c|c|c|c|c|}
\hline \multirow[b]{2}{*}{ Penicillium sp. } & \multirow[b]{2}{*}{ Host } & \multirow[b]{2}{*}{ Cultivar } & \multicolumn{3}{|c|}{$\mathrm{pH}$ value $\pm \mathrm{SE}^{\mathrm{z}}$} \\
\hline & & & Healthy & Decayed & $\Delta_{\mathrm{ph}}$ \\
\hline \multirow[t]{5}{*}{ P. expansum } & Apple & Granny Smith & $3.95 \pm 0.06$ & $3.64 \pm 0.01$ & 0.31 \\
\hline & & Gala & $4.31 \pm 0.06$ & $3.88 \pm 0.03$ & 0.43 \\
\hline & & Red Delicious & $4.44 \pm 0.03$ & $4.07 \pm 0.02$ & 0.37 \\
\hline & & Fuji & $4.44 \pm 0.06$ & $3.96 \pm 0.02$ & 0.48 \\
\hline & & Golden Delicious & $4.54 \pm 0.06$ & $3.88 \pm 0.03$ & 0.88 \\
\hline \multirow[t]{2}{*}{ P. digitatum } & Orange & Naval & $4.77 \pm 0.45$ & $3.12 \pm 0.07$ & 1.65 \\
\hline & Grapefruit & Oro Blanco & $4.74 \pm 0.05$ & $3.10 \pm 0.14$ & 1.64 \\
\hline \multirow[t]{2}{*}{ P. italicum } & Orange & Naval & $4.77 \pm 0.07$ & $3.02 \pm 0.13$ & 1.75 \\
\hline & Grapefruit & Oro Blanco & $4.55 \pm 0.13$ & $3.23 \pm 0.17$ & 1.32 \\
\hline
\end{tabular}

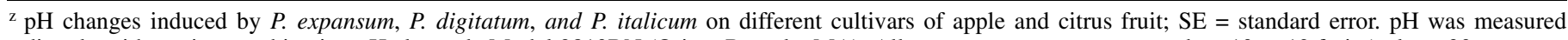
directly with a microcombination $\mathrm{pH}$ electrode Model 9810BN (Orion, Beverly, MA). All measurements were repeated on 10 to 12 fruit (at least 30 measurements) on the transverse axis of the lesion of each fruit. Measurements were taken 7 days after inoculation. 
The mechanism of acidification during colonization. In vitro organic acid production by $\mathrm{P}$. expansum and $\mathrm{P}$. digitatum. Analysis of organic acids secreted by $P$. expansum and $P$. digitatum during $24 \mathrm{~h}$ of growth in YSM indicated that citric acid was the main product, while minor amounts of fumaric and oxalic acid also were detected. For both Penicillium spp., when accumulation of citric acids was compared among cultures having the initial $\mathrm{pH}$ values of 3,5 , and 7 , the greatest amount of citric acid was produced at pH 5 after $24 \mathrm{~h}$ (Table 3).

In vivo organic acid accumulation induced by $\mathrm{P}$. expansum and P. digitatum. In grapefruit decayed by $P$. digitatum, citric acid content increased by $52 \%$ and gluconic acid content by $150 \%$ (Table 4). In $P$. expansum-decayed apple fruit, the accumulation of gluconic and fumaric acids increased from 0 to 1,586 and $6.0 \mu \mathrm{g} \mathrm{g}^{-1}$ fresh weight, respectively, and citric acid content increased by $64 \%$. In contrast, ascorbic acid declined significantly in these same experiments (Table 4). No significant amount of oxalic acid production was detected in decaying citrus or apple tissue. The addition of purified PG from $P$. expansum to wounded apple tissue did not induce any organic acid accumulation up to $48 \mathrm{~h}$ after the treatment in the macerated tissue (data not shown), suggesting that the host-pathogen interaction is needed for organic acid accumulation.

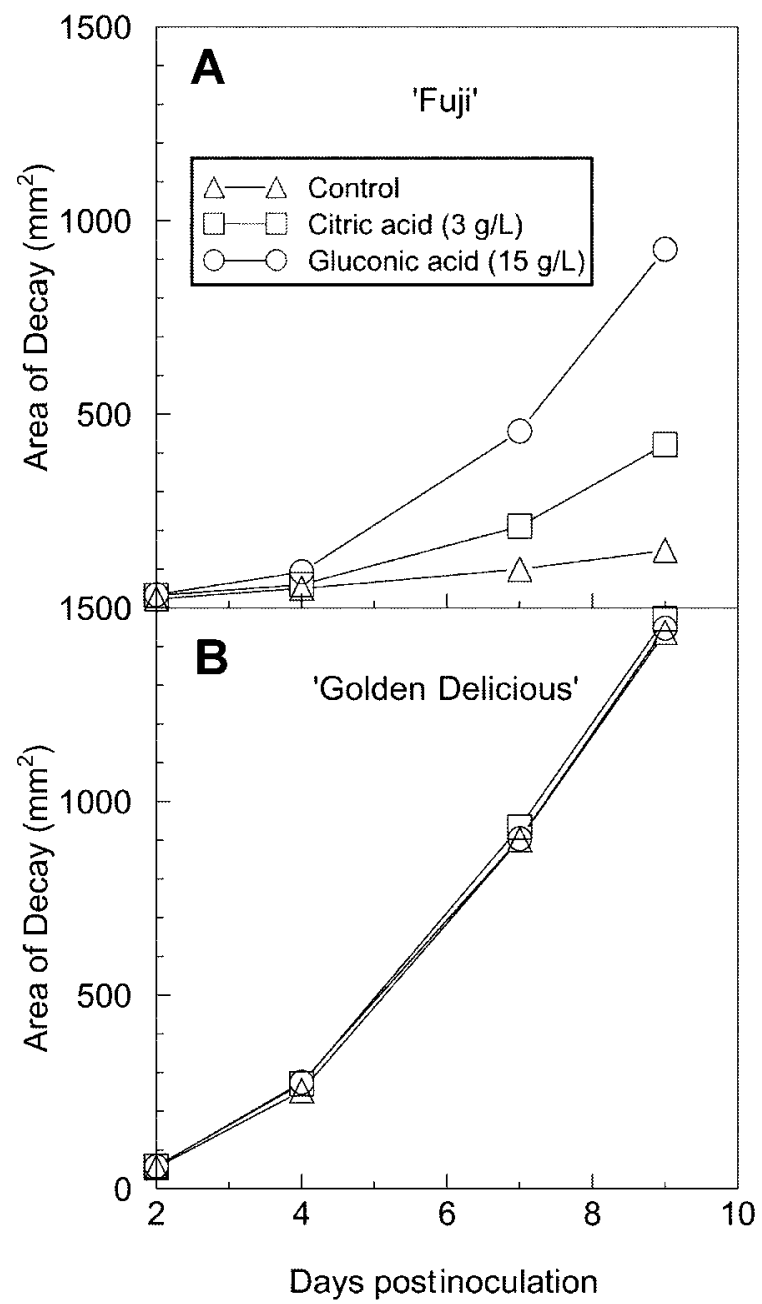

Fig. 1. Effect of citric and gluconic acid treatment on Penicillium expansum virulence in apples fruit of various initial $\mathrm{pH}$ values. A, Decay development of $P$. expansum in cv. Fuji with a pH at inoculation of 5.3. B, Effect of acid treatments on decay development of $\mathrm{cv}$. Golden Delicious with a $\mathrm{pH}$ at inoculation of 4.4. Ten fruit were wounded on four sides (40 inoculations) and $50 \mu \mathrm{l}$ of citric acid or gluconic acid was applied to the wound. One hour later, $25 \mu \mathrm{l}$ of P. expansum $\left(0.5 \times 10^{6} \mathrm{spores} / \mathrm{ml}\right)$ in water was applied to the wound. Lesion size was measured every second day during the first 9 days after inoculation.
Ambient $\mathrm{pH}$ and $\mathrm{NH}_{4}^{+}$influx induced by $P$. expansum, $P$. digitatum, and $\boldsymbol{P}$. italicum. The possibility that another mechanism of acidification is induced by Penicillium spp. was tested. When $P$. digitatum and $P$. italicum were transferred, during the inducing period, to a secondary medium containing $11 \mathrm{mM} \mathrm{NH}_{4} \mathrm{Cl}$ at $\mathrm{pH} 4.8$, the $\mathrm{NH}_{4}{ }^{+}$concentration in the medium decreased by $>75 \%$ in both $P$. digitatum (Fig. 3) and P. italicum (data not shown) cultures. During the same period, the $\mathrm{pH}$ of the culture media of $P$. digitatum and of $P$. italicum decreased to 3.8 and 3.1, respectively. In similar experiments in which $P$. expansum was transferred, during the inducing period, to a secondary medium containing $\mathrm{NH}_{4} \mathrm{Cl}$ at $\mathrm{pH} 5.0$, the $\mathrm{NH}_{4}{ }^{+}$concentration in the medium decreased by $>99 \%$ over a period of $17 \mathrm{~h}$. At the same time, the $\mathrm{pH}$ decreased from 5.0 to 2.4 (data not shown). Exposure of $P$. expansum hyphae to 100 to $200 \mu \mathrm{M}$ Na-orthovanadate or $20 \mu \mathrm{M}$ diethylstilbestrol partially inhibited $\mathrm{NH}_{4}{ }^{+}$depletion from the medium, with levels decreasing by 47 and $29 \%$, respectively.

Analysis of the ammonium content in the decayed tissue of three apple cultivars showed $>60 \%$ reduction in ammonium concentration and $\mathrm{pH}$ decreases of up to 0.6 units compared with healthy tissue in the same fruit (Table 5). Similar analysis of decayed grapefruit tissue showed an $\approx 50 \%$ reduction in ammonium concentration.

Ambient pH and pepg1 expression of $P$. expansum. The influence of ambient culture $\mathrm{pH}$ on the accumulation of transcripts encoding the endopolygalacturonase enzyme from $P$. expansum was examined by Northern blot analysis. Mycelia were transferred from primary cultures with an average $\mathrm{pH}$ of 5.5 to fresh secondary cultures with a series of $\mathrm{pH}$ values from 3.0 to 7.0. Analysis of the pepg 1 transcript levels with the $3^{\prime}$ UTR probe, $5 \mathrm{~h}$ after induction, showed that pepg 1 accumulation ranged between 3.5 and 5.0, but was highest at $\mathrm{pH} 4.0$ (Fig. 4). Minor expression was observed at $\mathrm{pH}$ values higher than 5.0 (data not shown).

\section{DISCUSSION}

Host $\mathrm{pH}$ modulation by pathogens recently was suggested as an important factor in enhancing the virulence of postharvest patho-

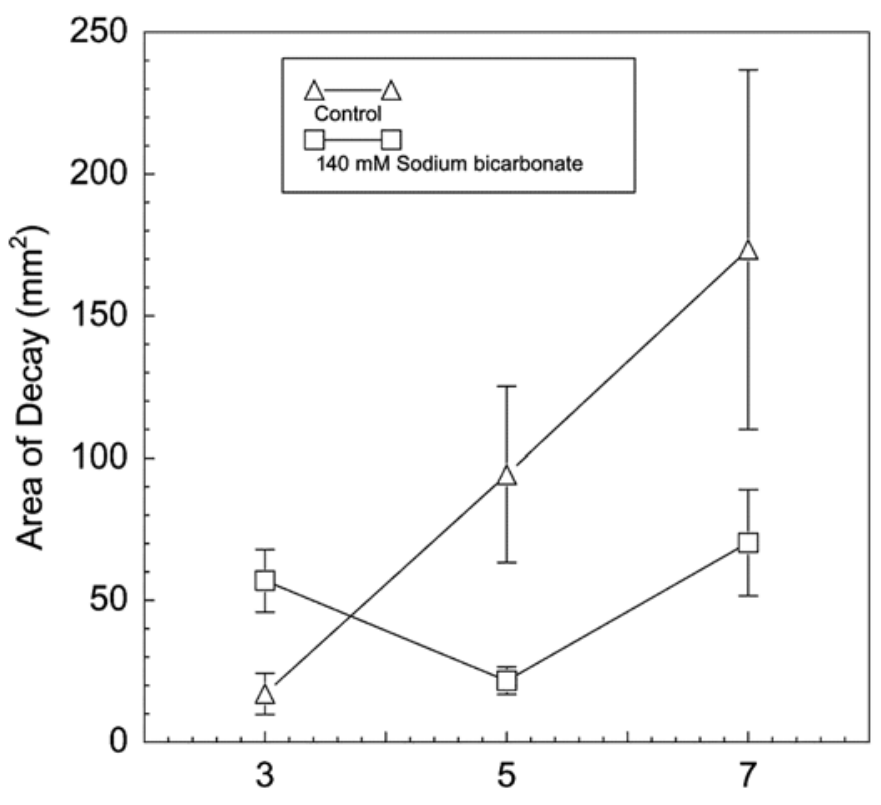

Days After Inoculation

Fig. 2. Modulation of Penicillium expansum virulence by Na-bicarbonate in apple fruit, cv. Golden Delicious. Ten fruit were wounded on four sides (40 inoculations) and $50 \mu \mathrm{l}$ of Na-bicarbonate $(140 \mathrm{mM})$ was applied to the wound. One hour later, $25 \mu \mathrm{l}$ of $P$. expansum $\left(0.5 \times 10^{6}\right.$ spores $\left./ \mathrm{ml}\right)$ in water was applied to the wound. Lesion size was measured daily during the first 8 days after inoculation. 
gens. Alkalinization of the ambient $\mathrm{pH}$ was shown to modulate pectolytic gene expression of hydrolases in Colletotrichum gloeosporioides (29) and of glucanases in A. alternata (11). C. gloeosporioides, $C$. acutatum, and $C$. coccodes locally increased ambient $\mathrm{pH}$ values by the secretion of ammonia in avocado, apple, and tomato fruit, respectively (29). In the present study, $P$. expansum, a broad-host-range phytopathogenic fungus, showed increased virulence as the $\mathrm{pH}$ of the apple fruit decreased. $P$. expansum also actively reduced the $\mathrm{pH}$ of the tissue by 0.3 to 0.6 during decay development in five apple cultivars. This is not the first observation that a pathogen decreased host $\mathrm{pH}$ during disease development. S. sclerotiorum reduced host $\mathrm{pH}$ during pathogenicity by secreting large amounts of oxalic acid, thus creating an acidic environment in which to grow and cause disease (15, $23,31)$. However, the present findings suggest that fungal virulence was affected by a combined effect of host and pathogen on ambient $\mathrm{pH}$ as found in avocado fruit (43). Examination of apple cultivars after storage indicated that, as the $\mathrm{pH}$ of the apple fruit became more acidic, $P$. expansum colonization increased. Furthermore, $P$. expansum colonization could be enhanced by treatments with exogenous citric and gluconic acids, or suppressed by $\mathrm{NaHCO}_{3}$ treatment, findings which, together, suggest that tissue acidification is a significant factor in determining virulence.

How do Penicillium spp. acidify the host tissue? The growth of $P$. expansum in the presence of $1.5 \%$ sucrose resulted in the accumulation of high levels of citric acid and a $\mathrm{pH}$ decrease from 7.0 and 5.0 to 4.5 and 4.2, respectively. The secretion of citric acid in culture by other Penicillium spp. has been reported previously (8). However, in the present study, the accumulation of citric and gluconic acids in decayed apple and grapefruit tissue suggest that the acidification of the tissue results, at least in part, from the accumulation of these acids. The concentration of citric acid in decayed apple was twice that found in healthy fruit; and, in citrus fruit, where the basal level of citric acid is much higher than in apple, the citric acid concentration increased by $50 \%$ during decay. Although gluconic acid production by $P$. expansum or $P$. digitatum was not detected under in vitro conditions, its accumulation during $P$. expansum- and $P$. digitatum-induced decay in apple and citrus fruit was higher than that of citric acid. In contrast to previous studies with Sclerotinia spp., oxalic acid accumulated only in minor amounts in Penicillium cultures and was not detected in decayed tissue. When $P$. expansum and $P$. digitatum were grown in the presence of sucrose, the highest citric acid pro-

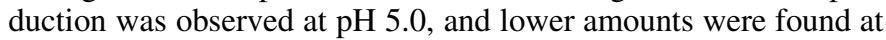
neutral $\mathrm{pH}$, suggesting a reduced efficiency to acidify fruit tissue having a $\mathrm{pH}$ higher than 7.0. Whether the pathogen itself or the host tissue, under induction by the pathogen, is the source of the organic acids being produced during decay is not clear. The occurrence of gluconic acids in decayed tissue might suggest the host contribution when affected by the pathogen. Our results suggest, however, that PGs produced by $P$. expansum are not the inducers of organic acid accumulation by the fruit.
P. expansum has developed a parallel mechanism for tissue acidification that involves the $\mathrm{NH}_{4}^{+}$uptake from the apple tissue. Ammonium concentrations decreased significantly in the acidified, decayed tissue. Ammonium is one of the preferred nitrogen sources for fungi, and Penicillium spp. take up $\mathrm{NH}_{4}{ }^{+}$efficiently (32) accompanied by stoichiometric $\mathrm{H}^{+}$excretion. Ross and Luckner (32) suggested the presence of an $\mathrm{H}^{+}$-translocating ATPase in $P$. cyclopium that functions as a proton pump under specific physiological conditions. It might be assumed that the plasma membrane possesses pathways for the permeation of the cationic species (22). The extent of the $\mathrm{NH}_{4}{ }^{+}$depletion from the medium and from decayed tissue suggests that $P$. expansum and $P$. digitatum have a significant ammonium-transport system or systems that may affect ambient $\mathrm{pH}$. The finding that ATPase inhibitors, such as $\mathrm{Na}$ orthovanadate and diethylstilbestrol, partially inhibited $\mathrm{NH}_{4}^{+}$influx in $P$. expansum further supports this suggestion.

What is the importance of tissue acidification for Penicillium spp. virulence? McCallum et al. (25) indicated that aggressive $P$. expansum isolates reduced $\mathrm{pH}$ faster than the weaker isolates. The capability of pathogens to acidify the environment has resulted in the expression of genes and the secretion of many hydrolytic enzymes encoding genes (4), including PGs $(17,31,38)$. Transcript analysis of the endoPG-encoding gene pepg 1 from $P$. expansum shows that it occurred between 3.5 and 5.0, with the highest transcript level observed at $\mathrm{pH}$ 4.0. pepg1 was shown to be expressed in vivo by Yao et al. (44) in decayed tissue that generally had a $\mathrm{pH}$ ranging between 3.6 and 4.0. Furthermore, our present results indicate that colonization of the tissue was faster in cultivars having a lower untreated tissue $\mathrm{pH}$ or if they were treated with organic acid. Organic acid treatment, however, could not enhance colonization in those cultivars where their untreated tissue $\mathrm{pH}$ was already low. Both results support the hypothesis that acidification of the tissue provides a better $\mathrm{pH}$ for pepg 1 expression.

TABLE 4. Organic acid presence in healthy and decayed 'Oro Blanco' grapefruit and 'Golden Delicious' apple inoculated with Penicillium digitatum and P. expansum, respectively

\begin{tabular}{lcccc}
\hline & \multicolumn{3}{c}{ Organic acids concentration $\left(\mu \mathrm{g} \mathrm{g}^{-1} \text { fresh weight }\right)^{\mathrm{z}}$} \\
\cline { 2 - 5 } Tissue & Citric & Fumaric & Ascorbic & Gluconic \\
\hline Grapefruit & & & & \\
Healthy & $5,979 \pm 234$ & 0 & $42 \pm 41$ & $6,320 \pm 2,470$ \\
Decayed & $9,097 \pm 362$ & 0 & $473 \pm 520$ & $15,832 \pm 2,980$ \\
Apple & & & & \\
Healthy & $591 \pm 280$ & 0 & $4 \pm 30$ & 0 \\
Decayed & $970 \pm 256$ & $6 \pm 1$ & 0 & $1,586 \pm 165$ \\
\hline
\end{tabular}

${ }^{\mathrm{z}}$ Average values \pm standard error. $\mathrm{pH}$ was determined with a microcombination pH electrode Model 9810BN (Orion, Beverly, MA). Organic acid concentrations were determined by high-performance liquid chromatography using a pure sample as a standard. All measurements were repeated four times from the decayed lesion of different fruit.

TABLE 3. Influence of $\mathrm{pH}$ on organic acid accumulation by Penicillium expansum and P. digitatum ${ }^{\mathrm{z}}$

\begin{tabular}{|c|c|c|c|c|}
\hline \multirow[b]{2}{*}{$\mathrm{pH}_{(\mathrm{i})}$} & \multirow[b]{2}{*}{$\mathrm{pH}_{(\mathrm{f})}$} & \multicolumn{3}{|c|}{ Organic acid $(\mu \mathrm{g} / \mathrm{ml})$} \\
\hline & & Citric acid $\Delta_{24-0 \mathrm{~h}}$ & Fumaric acid $\Delta_{24-0 \mathrm{~h}}$ & Oxalic acid $\Delta_{24-0 \mathrm{~h}}$ \\
\hline \multicolumn{5}{|c|}{ Secreted by $P$. expansum } \\
\hline 7.0 & 4.5 & $593 \mathrm{~b}$ & $8.0 \mathrm{~b}$ & $52.6 \mathrm{~b}$ \\
\hline \multicolumn{5}{|c|}{ Secreted by $P$. digitatum } \\
\hline 3.0 & 2.9 & $174 \mathrm{~b}$ & $6.8 \mathrm{a}$ & $\ldots$ \\
\hline
\end{tabular}

${ }_{\mathrm{z}}^{\mathrm{pH}}$ was determined with a microcombination $\mathrm{pH}$ electrode Model $9810 \mathrm{BN}$ (Orion, Beverly, $\mathrm{MA}$ ). $\mathrm{pH}_{(\mathrm{i})}=\mathrm{pH}$ of the culture before mycelia inoculation and $\mathrm{pH}_{(\mathrm{f})}=\mathrm{pH}$ of the culture $24 \mathrm{~h}$ after mycelia inoculation. Within treatments, the final $\mathrm{pH}$ values varied by 0.1 or less. Different letters indicate significant difference at $P \leq 0.05$, between the average of four replications of organic acid accumulation after transfer to inducing media with three different $\mathrm{pH}$ values. Experiments were repeated at least three times. The results of one representative experiment are presented. 
It should be pointed out that freshly harvested apple fruit and those stored commercially in optimal conditions (controlled atmosphere) usually show decay development only after a long storage period (4 to 6 months). This may suggest that the $\mathrm{pH}$ regulation of the environment would become critical following a decline of possible resistance mechanisms (e.g., preformed compounds, phenolic content, cell wall resistance, and so on). Under these conditions, the acidification of the environment by citric and gluconic acids, along with strong chelating activity of calcium and other ions (23), might have a synergistic effect and enhance the expression of genes and secretion of specific enzymes needed to facilitate fungal attack (29). Citric and gluconic acids accumulation were shown to decrease calcium concentration in the intercellular spaces of plant tissues and alter mineral balances and would, thereby, affect the stability of cell membranes and cell wall pectate polymers $(19,21)$. Destabilization of cell membranes and cell walls would enhance the sensitivity to pathogen-produced pectolytic enzymes similarly to what has been reported for oxalic acid (24). The secretion of organic acids also might have an indirect effect on pathogenesis by the suppression of fruit resistance. It was reported that the secretion of oxalate by $S$. sclerotiorum suppresses the plant oxidative burst (6). If this is combined with the reduction in host $\mathrm{pH}$ which inhibits the activities of plantproduced polyphenol oxidase $(21,25)$, this could result in a relatively broad and significant role in pathogenesis.

The extent of the effect of ambient $\mathrm{pH}$ on different pathogenic systems might suggest that $\mathrm{pH}$ is a regulator of gene expression
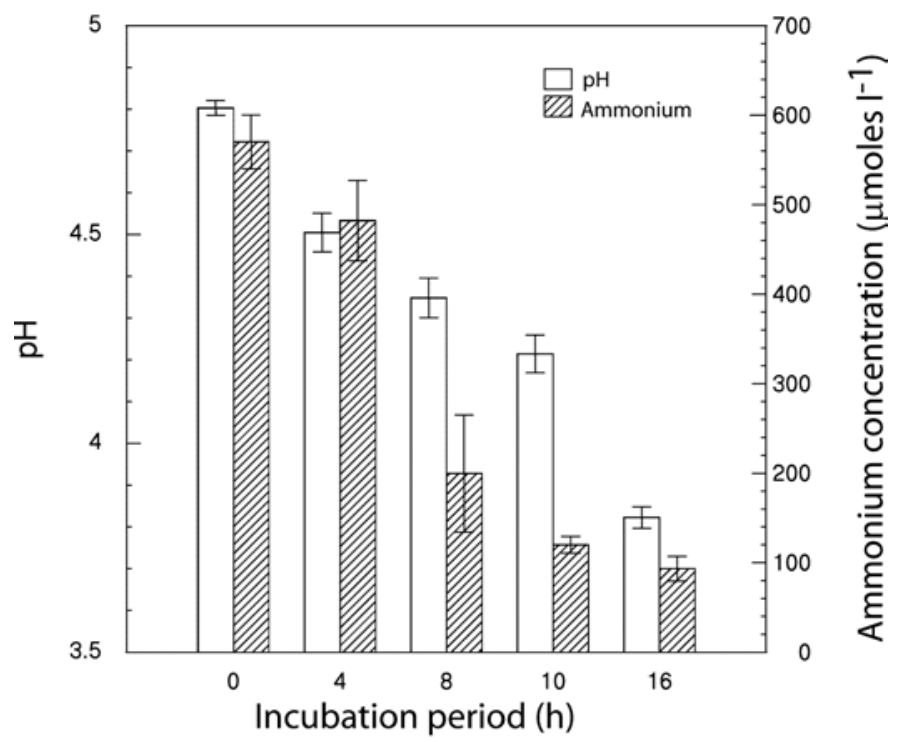

Fig. 3. Ammonium concentration and $\mathrm{pH}$ levels induced by Penicillium digitatum on $\mathrm{NH}_{4} \mathrm{Cl}$-containing media. Following growth in $\mathrm{M}_{3} \mathrm{~S}$ primary cultures, the hyphae were transferred to yeast sucrose medium, $\mathrm{pH} 4.8$. Direct $\mathrm{pH}$ and ammonium measurements were taken. Average of three replications and standard errors are presented. Experiments were repeated at least three times. The results of one representative experiment are presented.
$(5,11,29,31)$. In specific cases, the pathogen activates the mechanism of alkalinization and, in others, the mechanism of acidification. The principle behind the idea of ambient $\mathrm{pH}$ regulation is that this mechanism ensures that genes encoding extracellular enzymes are expressed and that their metabolites are secreted under the $\mathrm{pH}$ conditions at which they function best $(9,29)$. This would indicate that only specific enzymes out of the battery of enzymes produced by the pathogen are specifically involved. The pathogen would then actively change the environment to enhance the specific involvement of the preferred enzymes. However, the observation that optimal activity of the pure enzyme are not close enough to the optimum $\mathrm{pH}$ for gene expression suggests that disease incidence probably is dependent on gene expression and protein secretion rather than optimal enzyme activity. In those cases, the effect on the stability of cell membranes and cell wall pectate polymers created by the accumulation of oxalic (25), gluconic, or citric acid would enhance the sensitivity to pathogenproduced pectolytic enzymes in addition to the environmental conditions created by the ambient $\mathrm{pH}$ to secrete the protein. These findings suggest that $P$. expansum, $P$. digitatum, $P$. italicum, $C$.

\section{$\mathrm{pH}$ of medium}
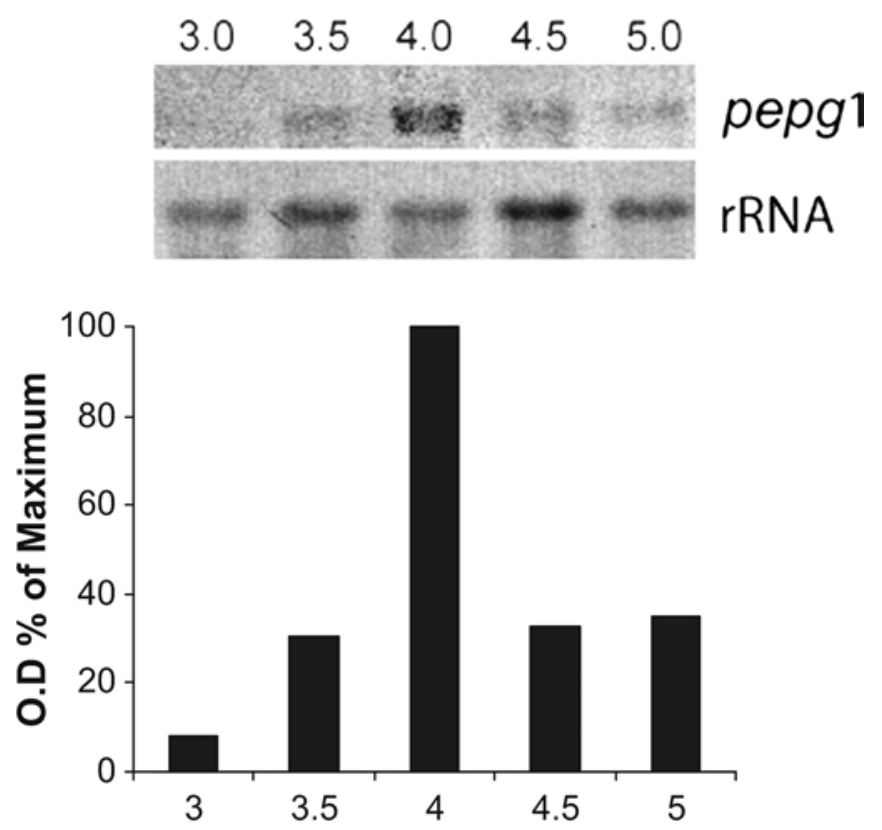

Fig. 4. pepg 1 transcript accumulation in response to different ambient $\mathrm{pH}$ conditions. Shown is a Northern analysis of total RNA isolated from Penicillium expansum mycelia $5 \mathrm{~h}$ after transfer to a fresh secondary yeast sucrose medium buffered with citrate-phosphate at the indicated $\mathrm{pH}$ values. The blot was probed with the 379-bp segment of pepgl and a ribosomal DNA (rDNA) fragment as indicated. The column at the bottom of each ribosomal DNA blot indicates the corrected percent intensity value of pepg 1 based on the background intensity and hybridization signal from the rDNA probe as determined with MacBAS software version 2.3 (Fujifilm).

TABLE 5. Ammonium concentrations and $\mathrm{pH}$ levels in healthy and Penicillium spp.-decayed fruit ${ }^{\mathrm{z}}$

\begin{tabular}{|c|c|c|c|c|}
\hline \multirow[b]{2}{*}{ Penicillium sp. and fruit cultivar } & \multicolumn{2}{|c|}{ Ammonium $(\mu \mathrm{M})$} & \multicolumn{2}{|c|}{$\mathrm{pH}$ value } \\
\hline & Healthy & Decayed & Healthy & Decayed \\
\hline \multicolumn{5}{|l|}{ P. expansum in apple } \\
\hline Golden Delicious & $201 \pm 34$ & $37 \pm 5$ & $4.06 \pm 0.14$ & $3.48 \pm 0.02$ \\
\hline Red Delicious & $165 \pm 21$ & $54 \pm 24$ & $4.04 \pm 0.07$ & $3.45 \pm 0.04$ \\
\hline \multicolumn{5}{|l|}{$P$. digitatum in grapefruit } \\
\hline Oro Blanco & $103 \pm 5.5$ & $52 \pm 15$ & $4.74 \pm 0.05$ & $3.10 \pm 0.14$ \\
\hline
\end{tabular}

$\mathrm{z}$ Averages \pm standard error of the means of three replications are presented. $\mathrm{pH}$ was determined with a microcombination pH electrode Model $9810 \mathrm{BN}($ Orion, Beverly, MA). 
gloeosporioides, and A. alternata could use the ambient $\mathrm{pH}$ environment where organic acids and ammonium is secreted as a regulatory cue for disease development. We recently found that Botrytis cinerea also decreased the $\mathrm{pH}$ of the decayed tissue (D. Prusky, unpublished data). Transcript levels of Bcpg3 encoding for PG in B. cinerea (41) also were activated under acidic conditions. In this case, the presence of a large endoPG gene family may enable the differential expression of the family members under different growth or host conditions. Together, these results suggest that local $\mathrm{pH}$ modulation by pathogens may be a more common mechanism than previously thought for increasing virulence during postharvest attack.

The finding that ambient $\mathrm{pH}$ may play a major regulatory role in pepg1 expression suggests the importance of ambient $\mathrm{pH}$ regulation by Penicillium spp. An ambient $\mathrm{pH}$ signal transduction pathway has been characterized in Aspergillus nidulans, and several components of this pathway, including the $\mathrm{pH}$-dependent transcriptional regulator $p a c \mathrm{C}$, have been cloned and characterized in $S$. sclerotiorum $(31,39)$ and C. gloeosporioides $(10,28)$. pacC homologs also have been identified in $P$. expansum (Hadass, Pines, and Prusky, accession no. AY225524) and in the closely related filamentous fungus A. niger (18), in P. chrysogenum (37), in yeasts $(16,30,36,40)$, and, more recently, in Fusarium oxysporum f. sp. lycopersici (5). Ambient $\mathrm{pH}$ sensing and gene regulation may be one basis for viable strategies for blocking disease development by a broad range of postharvest pathogens.

\section{ACKNOWLEDGMENTS}

We thank V. Gaskins for her significant help in various aspects of this work, W. Douglas for his help in the development of high-performance liquid chromatography for organic acids acid quantification, and $\mathrm{K}$. Green for her encouragement and help.

\section{LITERATURE CITED}

1. Ausubel, F. M., Brent, R., Kingston, R. E., Moore, D. D., Seidman, J. G., Smith, J. A., and Struhl, K. 1991. Current Protocols in Molecular Biology. John Wiley \& Sons, Inc., New York.

2. Barmore, C. R., and Brown, G. E. 1981. Polygalacturonase from citrus fruit infected with Penicillium italicum. Phytopathology 71:328-331.

3. Bateman, D. F., and Basham, H. G. 1976. Degradation of plant cell walls and membranes by microbial enzymes. Encycl. Plant Physiol. New Ser. 4:316-355.

4. Bateman, D. F., and Beer, S. V. 1965. Simultaneous production and synergistic action of oxalic acid and polygalacturonase during pathogenesis by Sclerotium rolfsii. Phytopathology 58:204-211.

5. Caracuel, Z., Roncero, M. G, Gonzales-Verdejo, C., and Di Pietro, A. 2002. The $\mathrm{pH}$ response transcription factor $\mathrm{PacC}$ controls virulence in $\mathrm{Fu}$ sarium oxysporum. (Abstr. 368) 6th Eur. Conf. Fungal Genet. Pisa, Italy.

6. Cessna, S., Sears, V., Dickman, M., and Low, P. 2000. Oxalic acid, a pathogenicity factor of Sclerotinia sclerotiorum, suppresses the host oxidative burst. Plant Cell 12:2191-2199.

7. Church, G. M., and Gilbert, W. 1984. Genomic sequencing. Proc. Natl. Acad. Sci. USA 81:1991-1995.

8. Cunningham, J. E., and Kuiack, C. 1992. Production of citric and oxalic acids and solubilization of calcium phosphate by Penicillium bilaii. Appl. Environ. Microbiol. 58:1451-1458.

9. Denison, S. H. 2000. pH regulation of gene expression in fungi. Fungal Genet. Biol. 29:61-71.

10. Drori, N., Kramer,-Haimovich, H., Rollins, J., Dinoor, A., Okon, Y., Pines, O., and Prusky, D. 2003. External pH and nitrogen source affect secretion of pectate lyase by Colletotrichum gloeosporioides. Appl. Environ. Microbiol. 69:3258-3262.

11. Eshel, D., Miyara, I., Ailinng, T., Dinoor, A., and Prusky, D. 2002. pH regulates endoglucanase expression and virulence of Alternaria alternata in persimmon fruits. Mol. Plant-Microbe Interact. 15:774-779.

12. Free, S. J., Rice, P. W., and Metzenberg, R. L. 1979. Arrangement of genes coding for ribosomal ribonucleic acids in Neurospora crassa. J. Bacteriol. 137:1219-1226.

13. Jones, T. M., Anderson, A. J., and Albersheim, P. 1972. Host-pathogen interactions. IV. Studies on the polysaccharide-degrading enzymes secreted by Fusarium oxysporum f. sp. lysopersici. Physiol. Plant Pathol. 2:153-166.
14. Karr, A. L., and Albersheim, P. 1970. Polysaccharide-degrading enzymes are unable to attack plant cell walls without prior action by "wallmodifying-enzyme." Plant Physiol. 46:69-80.

15. Kubicek, C. P., Schreferl-Kunar G., Wöhrer, W., and Röhr, M. 1988. Evidence for a cytoplasmic pathway of oxalate biosynthesis in Aspergillus niger. Appl. Environ. Microbiol. 54:633-637.

16. Lambert, M., Blanchin-Roland, S., Le Louedec, F., Lépingle, A., and Gaillardin, C. 1997. Genetic analysis of regulatory mutants affecting synthesis of extracellular proteinases in the yeast Yarrowia lipolytica: Identification of a RIM101/pacC homolog. Mol. Cell. Biol. 17:39663976.

17. Lumsden, R. D. 1976. Pectolytic enzymes of Sclerotinia sclerotiorum and their localization in infected bean. Can. J. Bot. 54:2630-2641.

18. MacCabe, A. P., van den Hombergh, J. P. T. W., Tilburn, J., Arst, H. N., Jr., and Visser, J. 1996. Identification, cloning and analysis of the Aspergillus niger gene pac $\mathrm{C}$, a wide domain regulatory gene responsive to ambient pH. Mol. Gen. Genet. 250:367-374.

19. Magro, P., Marciano, P., and Di Lenna, P. 1984. Oxalic acid production and its role in pathogenesis of Sclerotinia sclerotiorum. FEMS Microbiol. Lett. 24:9-12.

20. Mankarios, A. T., and Friend, J. 1980. Polysaccharide-degrading enzymes of Botrytis allii and Sclerotiorum cepivorum: Enzyme production in culture and the effect of enzymes on isolated onion cell walls. Physiol. Plant Pathol. 17:93-104.

21. Marciano, P., Di Lenna, P., and Magro, P. 1983. Oxalic acid, cell walldegrading enzymes and $\mathrm{pH}$ in pathogenesis and their significance in the virulence of two Sclerotinia sclerotiorum isolates on sunflower. Physiol. Plant Pathol. 22:339-345.

22. Marini, A. M., Boudekou, S. S., Vissers, S., and Andre, B. 1997. A family of ammonium transporters in Saccharomyces cervisiae. Mol. Cell. Biol. 17:4282-4293.

23. Martell, A. E., and Calvin, M. 1952. Pages 516 and 541 in: Chemistry of the Metal Chelate Compounds. Prentice-Hall, Inc., New York.

24. Maxwell, D. P., and Lumsden, R. D. 1970. Oxalic acid production by Sclerotinia sclerotiorum in infected bean and in culture. Phytopathology 60:1395-1398.

25. McCallum, J. L., Tsao, R., and Zhou, T. 2002. Factors affecting patulin production by Penicillium expansum. J. Food Prot. 65:1937-1942.

26. Oren-Samir, M., Pick, U., and Avron, M. 1989. Involvement of the plasma membrane ATPase in the osmoregulatory mechanism of the alga Dunaliella salina. Plant Physiol. 89:1258-1263.

27. Prusky, D., Gold, S., and Keen, N. T. 1989. Purification and characterization of an endopolygalacturonase produced by Colletotrichum gloeosporioides. Physiol. Mol. Plant Pathol. 35:121-133.

28. Prusky, D., McEvoy, J. L., and Conway, W. S. 2002. Local pH modulation by pathogens as a mechanism to increase virulence. (Abstr. 319) 6th Eur. Conf. Fungal Genet. Pisa, Italy.

29. Prusky, D., McEvoy, J. L., Leverentz, B., and Conway, W. S. 2001. Local modulation of host $\mathrm{pH}$ by Colletotrichum species as a mechanism to increase virulence. Mol. Plant-Microbe Interact. 14:1105-1113.

30. Ramon, A. M., Porta, A., and Fonzi, W. A. 1999. Effect of environmental $\mathrm{pH}$ on morphological development of Candida albicans is mediated via the PacC-related transcription factor encoded by PRR2. J. Bacteriol. 181:7524-7530.

31. Rollins, J. A., and Dickman, M. B. 2001. pH signaling in Sclerotinia sclerotiorum: Identification of pacC/RIM1 homolog. Appl. Environ. Microbiol. 67:75-81.

32. Ross, W., and Luckner, M. 1984. 1984. Relationship between proton extrusion and fluxes of ammonium ions and organic acids in Penicillium cyclopium. J. Gen. Microbiol. 130:1007-1014.

33. Scott-Craig, J. S., Panacccione, D. G., Cervone, F., and Walton, J. D. 1990. Endopolygalacturonase is not required for pathogenicity of Cochliobolus carbonum on maize. Plant Cell 2:1191-1200.

34. Shieh, M., Brown, R. L., Whitehead, M. P., Carey, J. W., Cotty, P. J., Cleveland, T. E., and Dean, R. A. 1997. Molecular genetic evidence for the involvement of a specific polygalacturonase, $\mathrm{P} 2 \mathrm{c}$, in the invasion and spread of Aspergillus flavus in cotton bolls. Appl. Environ. Microbiol. 63:3548-3552.

35. St. Leger, R. A., Joshi, L., and Roberts, D. 1998. Ambient pH is a major determinant in the expression of cuticle-degrading enzymes and hydrophobin by Metarhiziyum anisopliae. Appl. Environ. Microbiol. 64:709-713.

36. Su, S. S. Y., and Mitchell, A. 1993. Molecular characterization of the yeast meiotic regulatory gene RIM1. Nucleic Acids Res. 21:3789-3797.

37. Suárez, T., and Peñalva, M. A. 1996. Characterization of a Penicillium chrysogenum gene encoding a PacC transcription factor and its binding sites in the divergent $p c b A B-p c b C$ promoter of the penicillin biosynthetic cluster. Mol. Microbiol. 20:529-540.

38. ten Have, A., Mulder, W., Visser, J., and van Kan, J. A. L. 1998. The endopolygalacturonase gene Bcpg1 is required for full virulence of Botrytis cinerea. Mol. Plant-Microbe Interact. 11:1009-1016. 
39. Tilburn, J., Sarkar, S., Widdick, D. A., Espeso, E. A., Orejas, M., Mungroo, J., Peñalva, M. A., and Arst, H. N., Jr. 1995. The Aspergillus PacC zinc finger transcription factor mediates regulation of both acidicand alkaline-expressed genes by ambient pH. EMBO J. 14:779-790.

40. Wilson, R. B., Davis, D., and Mitchell, A. P. 1999. Rapid hypothesis testing with Candida albicans through gene disruption with short homology regions. J. Bacteriol. 181:1868-1874.

41. Wubben, J. P., ten Have, A., van Kan, J. A. L., and Visser, J. 2000. Regulation of endopolygacturonase gene expression in Botrytis cinerea by galacturonic acid, ambient $\mathrm{pH}$ and carbon catabolite repression. Curr. Genet. 37:152-157.
42. Yakoby, N., Beno-Moualem, D., Keen, N. T., Dinoor, A., Pines, O., and Prusky, D. 2001. Colletotrichum gloeosporioides pelB, is an important factor in avocado fruit infection. Mol. Plant-Microbe Interact. 14:988995.

43. Yakoby, N., Kobiler, I., Dinoor, A., and Prusky, D. 2000. pH regulation of pectate lyase secretion modulates the attack of Colletotrichum gloeosporioides on avocado fruits. Appl. Environ. Microbiol. 66:10261030.

44. Yao, C., Conway, W. S., and Sams, C. E. 1996. Purification and characterization of a polygalacturonase produced by Penicillium expansum in apple fruit. Phytopathology 86:1160-1166. 